\title{
ISOLASI JAMUR ENDOFIT RIMPANG KUNYIT HITAM (CURCUMA CAESIA ROXB.)
}

\author{
Hidayat G.A, Wahyu Widayat, Rolan Rusli* \\ Laboratorium Penelitian dan Pengembangan FARMAKA TROPIS Fakultas Farmasi \\ Universitas Mulawarman Samarinda Kalimantan Timur \\ email: rolan@farmasi.unmul.ac.id
}

\begin{abstract}
ABSTRAK
Jamur endofit merupakan mikroorganisme yang terdapat di dalam suatu sistem jaringan tumbuhan seperti biji, daun, bunga, ranting, batang dan akar. Berbagai senyawa fungsional dapat dihasilkan oleh jamur endofit. Kunyit Hitam (Curcuma caesia Roxb.) merupakan herba hijau yang berasal dari India, termasuk dalam kategori rempah dan tersebar di kawasan tropika. Tujuan penelitian ini adalah untuk mengisolasi dan mengetahui ciri secara makroskopik dan mikroskopik jamur endofit yang terdapat pada rimpang kunyit hitam. Penelitian dilakukan dengan mengisolasi jamur endofit dari rimpang kunyit hitam menggunakan medium Potato Dextrose Agar Chloramphenicol (PDAC) dan Yeast Extract Agar Chloramphenicol (YEAC) kemudian dilakukan pemurnian pada jamur endofit serta mengkarakterisasi isolat jamur endofit. Hasil penelitian adalah diperoleh lima isolat jamur endofit yang tumbuh pada rimpang kunyit hitam, yaitu isolat jamur endofit hijau 2, isolat jamur endofit putih 2, dan isolat jamur endofit coklat.
\end{abstract}

Kata Kunci: Jamur endofit, isolasi, kunyit hitam (Curcuma caesia Roxb.)

\begin{abstract}
Endophytic fungi is microorganisms contained in a system of plant tissues such as seeds, leaves, flowers, twigs, stems and roots. Various functional compounds can be produced by the endophytic fungi. Black Turmeric (Curcuma caesia Roxb.) is a green herb that originated from India, including in the category of herbs and spread over the tropis area. Endophytic fungi was isolated from turmeric black using medium Potato Dextrose Agar Chloramphenicol (PDAC), Malt Extract Agar Chloramphenicol (MEAC), and Yeast Extract Agar Chloramphenicol (YEAC). Endophytic fungi from turmeric black was obtained 5 isolates, viz 2 green isolates, 2 white isolates, and 1 brown isolates.
\end{abstract}


Keywords: endophytic fungi, isolation, black turmeric (Curcuma caesia Roxb.)

\section{PENDAHULUAN}

Tanaman Kunyit Hitam (Curcuma caesia Roxb.) merupakan herba hijau dengan rimpang hitam kebiruan adalah mempunyai daun hijau yang besar dan bergelombang rendah dengan sisi atas yang kasar dan berwarna ungu tua serta memiliki pelepah berwarna merah di tengah daun.

Di India, kunyit hitam juga digunakan untuk mengobati berbagai sakit dan dipercaya sebagai tanaman penolak bala dan tanaman keberuntungan. Beberapa aktivitas kunyit hitam yang telah diuji yaitu aktivitas antifungal, antiasma, bronkodilatasi, antioksidan, Cerebrospinal Neuro System (CNS) depresan, antikonvulsan, anthelmintik, antimutagenik, antibakteri dan anti ulcer.

Jamur endofit merupakan mikroorganisme yang terdapat di dalam suatu sistem jaringan tumbuhan seperti biji, daun, bunga, ranting, batang dan akar. Sebagai sumber daya yang baru dan melimpah, jamur endofit memiliki kemampuan khusus untuk menghasilkan senyawa yang serupa dengan senyawa yang berasal dari tanaman inangnya, serta senyawa bioaktif lainnya.

Dengan demikian potensi ini dapat dikembangkan dengan isolasi jamur endofit, khususnya pada jaringan rimpang kunyit hitam karena secara tradisional, kunyit hitam digunakan untuk mengobati kista, kanker, asma, impotensi, epilepsi, gangguan haid, demam tinggi, luka bakar, jerawat, perawatan kulit, alergi, sakit gigi, dan fertilitas. Oleh karena itu, dalam penelitian ini dilakukan isolasi dan karakterisasi jamur endofit yang terdapat pada rimpang kunyit hitam.

\section{METODE}

\section{Alat dan Bahan}

Alat yang digunakan dalam penelitian ini yaitu timbangan analitik, autoklaf, inkubator, cawan petri, erlenmeyer, gelas kimia, spoit injeksi, hot plate, bisturi, Laminar Air Flow, mikroskop kamera dan alat penunjang lainnya. Bahan penelitian ini yaitu rimpang kunyit hitam (Curcuma caesia Roxb). Untuk sterilisasi permukaan rimpang kunyit hitam digunakan alkohol 70\% dan $\mathrm{NaOCl}$ 5,25\%. Medium yang digunakan adalah Potato Dextrose Agar/ PDA (Merck) yang ditambahkan kloramfenikol selanjutnya disebut Potato Dextrose 
Agar Chloramphenicol (PDAC) dan Yeast Extract Agar/YEA (Merck) yang ditambahkan kloramfenikol selanjutnya disebut Yeast Extract Agar Chloramphenicol (YEAC). Bahan yang digunakan untuk uji mikroskopik yaitu gliserin, kertas saring dan methylene blue.

\section{Isolasi Jamur Endofit}

Isolasi jamur endofit dilakukan dengan metode tanam langsung. Rimpang kunyit hitam dibersihkan terlebih dahulu menggunakan air suling yang mengalir untuk menghilangkan kotoran di bagian permukaan. Rimpang kunyit hitam kemudian direndam dalam etanol $70 \%$ selama 1 menit, lalu dilanjutkan dengan perendaman dalam larutan natrium hipoklorit 5,3\% selama 3 menit, direndam kembali dalam etanol $70 \%$ selama 30 detik dan terakhir dicelupkan dalam aquades sebanyak 5 kali. Selanjutnya rimpang kunyit hitam ditiriskan dan dibagi menjadi 4 potongan masing-masing berukuran lebih kurang $1 \mathrm{x}$ $1 \mathrm{~cm}$. Masing-masing potongan sampel diletakkan pada permukaan medium PDAC dan YEAC yang telah memadat dengan posisi bagian jaringan daun menempel pada medium, dalam satu cawan petri berisi 6 potongan sampel dengan tiga kali replikasi pada masing masing medium. Diinkubasi selama 7-14 hari pada suhu $25^{\circ} \mathrm{C}$.

\section{Pemurnian Jamur Endofit}

Pemurnian dilakukan untuk memisahkan koloni jamur endofit hingga diperoleh isolat jamur endofit. Koloni jamur yang tumbuh di sekeliling sampel rimpang kunyit hitam dimurnikan berdasarkan morfologi makroskopik yang dapat diamati dari warna serta pertumbuhan koloni jamur. Masing-masing isolat jamur endofit yang diperoleh, kemudian dipindahkan menggunakan ose ke dalam media PDAC dan YEAC pada cawan petri untuk memisahkan koloni endofit dengan morfologi berbeda untuk dijadikan isolat tersendiri.. Diinkubasi selama 5-7 hari pada suhu $25^{\circ} \mathrm{C}$, jika pada saat pengamatan ditemukan pertumbuhan koloni yang berbeda secara makroskopis maka dipisahkan kembali hingga diperoleh isolat murni.

\section{Karakterisasi Isolat Jamur Endofit}

Karakterisasi isolat jamur endofit dengan melakukan pengamatan ciri-ciri makroskopik dan mikroskopik. Karakterisasi secara makroskopik ini dilakukan dengan pengamatan isolat jamur endofit yang telah murni meliputi warna koloni, bentuk koloni, dan 
elevasi. Karakterisasi secara mikroskopik ini dilakukan pengamatan menggunakan preparat isolat jamur endofit melalui mikroskop. Terdapat dua jenis metode mikroskopik yaitu metode mikroskopik langsung. Metode mikroskopik langsung dilakukan dengan meneteskan methylen blue yang telah diinokulasikan isolat jamur endofit dan diamati menggunakan mikroskop. Sedangkan metode mikroskopik tidak langsung dilakukan dengan cara diinokulasikan isolat jamur endofit di atas medium PDA yang ada di object glass dan dibuat dalam kondisi lembab dengan gliserin yang ditetesi pada kertas saring sebagai pelapis cawan petri, kemudian diinkubasi selama 5-7 hari pada suhu $25^{\circ} \mathrm{C}$, selanjutnya diamati menggunakan mikroskop.

\section{HASIL DAN PEMBAHASAN}

a. Isolasi Jamur Endofit

Isolasi jamur endofit dari tanaman yang berbeda ataupun dari bagian tanaman yang berbeda tetapi dari satu tumbuhan inang memiliki jenis isolat jamur yang berbeda. Isolasi jamur endofit terlebih dahulu dilakukan sterilisasi permukaan sampel sebelum ditanamkan dalam medium. Sterilisasi permukaan sampel dilakukan dengan cara merendam sampel dalam alkohol $70 \%$, kemudian $\mathrm{NaOCl} 5,3 \%$, lalu direndam kembali dalam alkohol 70\%, dan terakhir dicelupkan dalam aquades. Proses sterilisasi permukaan untuk dapat menjamin sterilitas permukaan sampel dari kontaminasi organisme. Alkohol $70 \%$ berfungsi untuk sterilisasi permukaan tetapi alkohol $70 \%$ memiliki spektrum yang sempit sehingga perlu dikombinasikan dengan bahan kimia lainnya dan biasanya dikombinasikan dengan $\mathrm{NaOCl} 5,3 \%$. Dicelupkan kedalam aquades berfungsi untuk menghilangkan residu alkohol 70\% dan $\mathrm{NaOCl}$ 5,3\% yang terdapat pada permukaan sampel. Sampel yang telah disterilisasi permukaannya kemudian dipotong dan jaringannya ditempelkan pada medium yang telah memadat. Medium yang digunakan saat isolasi yaitu medium PDA yang ditambahkan dengan kloramfenikol (PDAC) dan medium YEA yang ditambahkan dengan kloramfenikol (YEAC), hal ini dilakukan untuk menekan pertumbuhan bakteri endofit dan bakteri patogen yang kemungkinan ikut tumbuh saat isolasi. Dari rimpang kunyit hitam (Curcuma caesia Roxb.), diperoleh total 5 isolat jamur endofit, yaitu 2 isolat berasal dari isolasi jamur endofit menggunakan medium YEAC dan 3 isolat berasal dari isolasi jamur endofit menggunakan medium PDAC. Hasil isolasi dari rimpang kunyit hitam setelah dilakukan pengamatan selama 2 minggu dapat dilihat pada Gambar 1.

Jamur endofit yang tumbuh di sekeliling potongan rimpang kunyit hitam dimurnikan hingga memperoleh isolat jamur endofit. Pemisahan dilakukan berdasarkan warna dan 
bentuk koloni jamur yang kemudian dipindahkan ke dalam medium yang baru. Berdasarkan Gambar 1, hasil isolasi yang terlihat pada masing-masing cawan petri memiliki warna dan bentuk koloni yang berbeda. Isolat jamur endofit dengan kode isolat $\mathrm{GT}_{1}$ dan $\mathrm{GT}_{2}$ diisolasi dari rimpang kunyit hitam dengan medium YEAC. Isolat jamur endofit dengan kode isolat $\mathrm{GT}_{3}, \mathrm{GT}_{4}$, dan $\mathrm{GT}_{5}$ diisolasi dari rimpang kunyit hitam dengan medium PDAC.
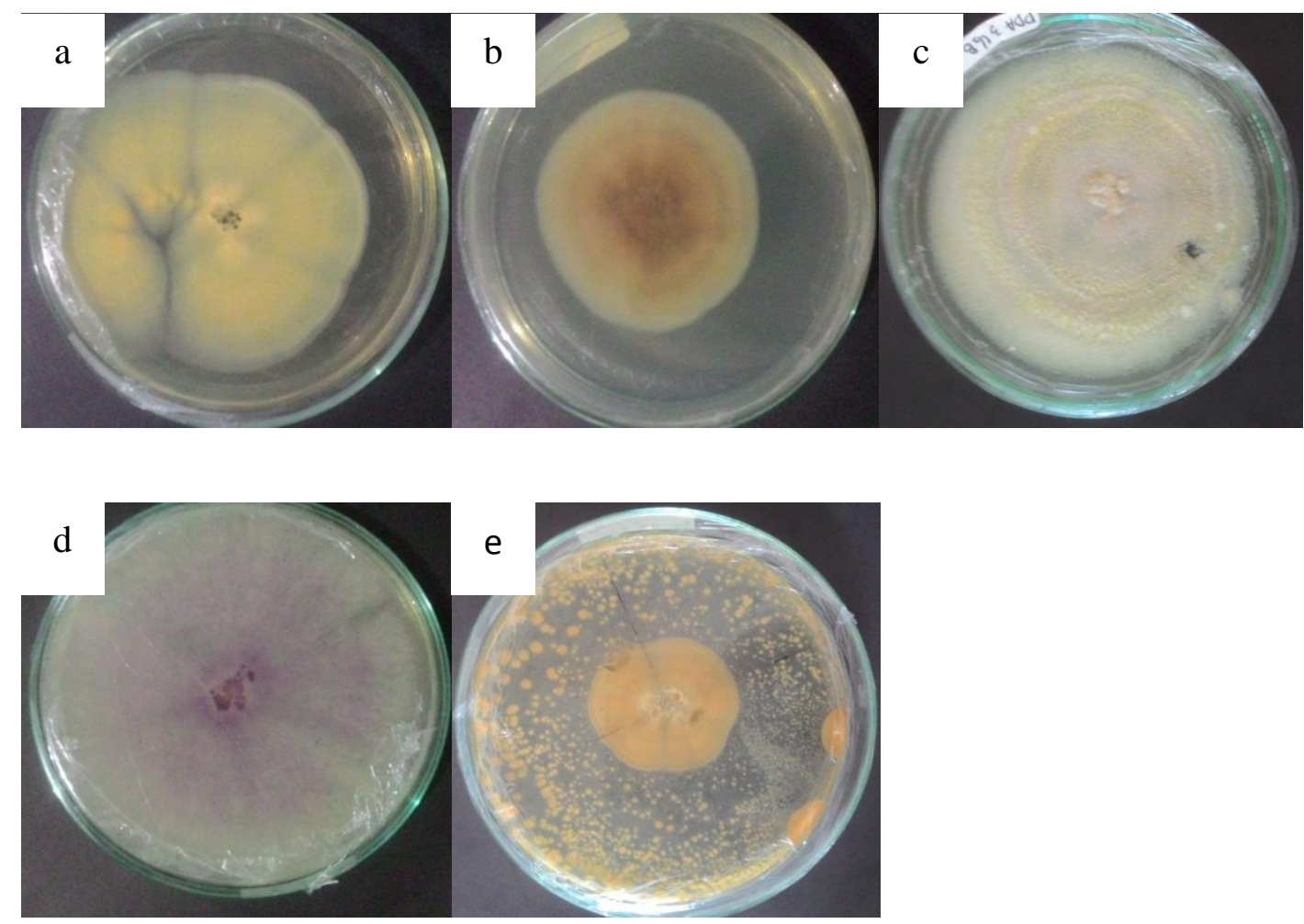

Gambar 1. Jamur Endofit dari rimpang kunyit hitam (Curcuma caesia Roxb.) setelah inkubasi selama 2 minggu, (a) $\mathrm{GT}_{1}$, (b) $\mathrm{GT}_{2}$, (c) $\mathrm{GT}_{3}$, (d) $\mathrm{GT}_{4}$, dan (e) $\mathrm{GT}_{5}$.

b. Karakterisasi Isolat Jamur Endofit

Isolat jamur endofit dari rimpang kunyit hitam yang telah murni selanjutnya dikarakterisasi untuk melihat ciri-ciri jamur secara makroskopik dan mikroskopik. Hasil isolasi jamur endofit dari rimpang kunyit hitam dapat dilihat pada Gambar 2. 

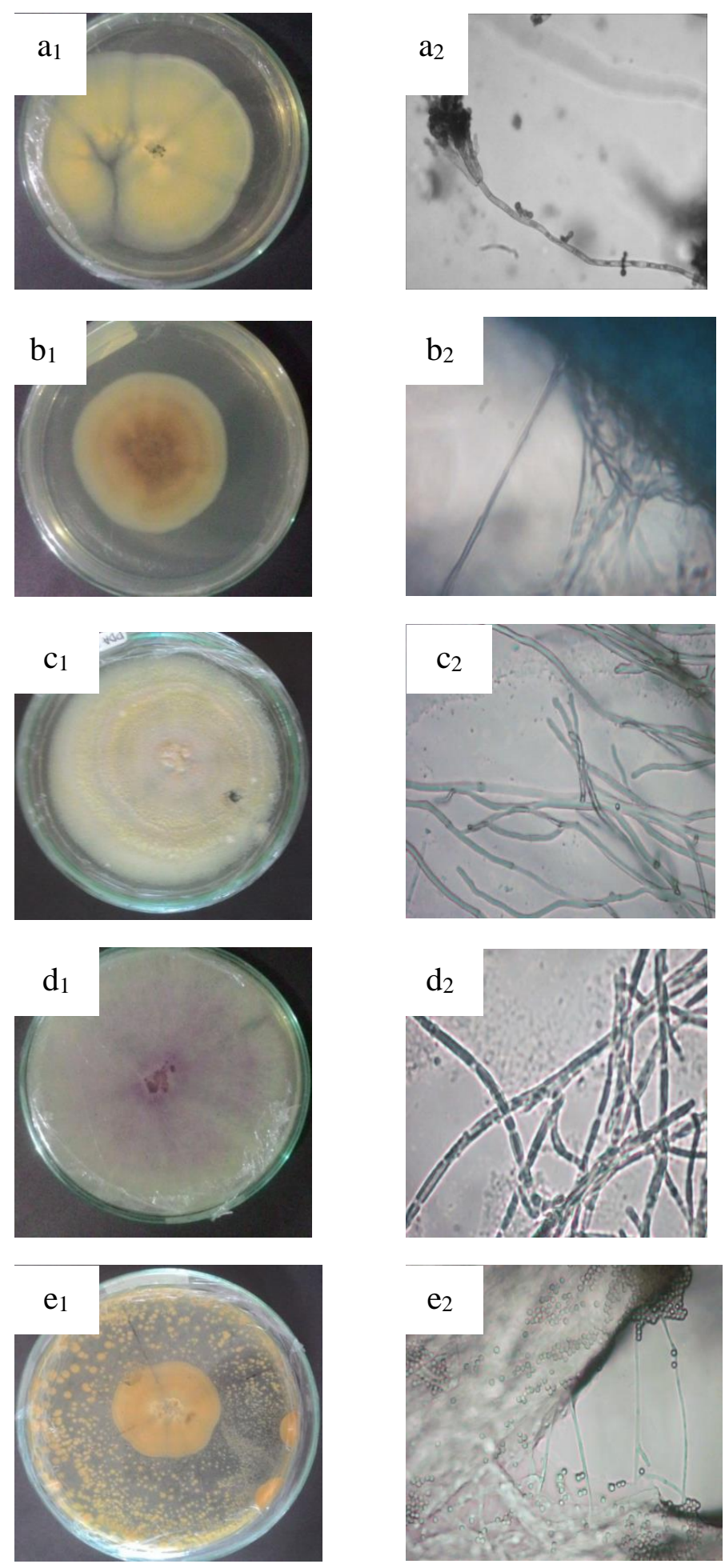

Gambar 2. Isolat jamur endofit rimpang kunyit hitam (Curcuma caesia Roxb.). Diperoleh lima isolat jamur endofit yaitu (a1) isolat jamur endofit hijau 1, (a2) hasil pengamatan mikroskopik isolat jamur endofit hijau 1, (b1) isolat jamur endofit cokelat, (b2) hasil pengamatan mikroskopik isolat jamur endofit cokelat, (c1) isolat jamur endofit putih 1, (c2) hasil pengamatan mikroskopik isolat jamur endofit putih 1, (d1) isolat jamur endofit putih 2, (d2) hasil pengamatan mikroskopik isolat jamur endofit putih 2, dan (e1) isolat jamur endofit hijau 2, (e2) hasil pengamatan mikroskopik isolat jamur endofit hijau 2. 
Berdasarkan Gambar 2 dapat dilihat hasil isolasi jamur endofit dari rimpang kunyit hitam (Curcuma caesia Roxb.) diperoleh lima isolat jamur endofit yaitu isolat jamur endofit hijau 2, isolat jamur endofit putih 2, dan isolat jamur endofit coklat. Hasil pengamatan makroskopik pada isolat jamur endofit hijau 1 yang tumbuh pada medium YEA memiliki warna permukaan koloni hijau dengan tepi putih, bentuk koloni irregular, elevasi flat dengan permukaan halus. Hasil pengamatan mikroskopis pada isolat jamur endofit hijau 1 memiliki hifa, septa, dan konidia. Pengamatan makroskopik pada isolat jamur endofit cokelat yang tumbuh pada medium YEA memiliki warna permukaan koloni cokelat dengan tepi kuning, bentuk koloni circular, elevasi flat dengan permukaan halus. Hasil pengamatan mikroskopis pada isolat jamur endofit coklat memiliki hifa. Pengamatan makroskopik pada isolat jamur endofit putih 1 yang tumbuh pada medium PDA memiliki warna permukaan koloni putih, bentuk koloni circular dan elevasi flat dengan permukaan halus. Pengamatan mikroskopis pada isolat jamur endofit putih 1 memiliki hifa.

Pengamatan makroskopik pada isolat jamur endofit putih 2 yang tumbuh pada medium PDA memiliki warna permukaan koloni putih, bentuk koloni filamentous dan elevasi flat dengan permukaan seperti kapas. Pengamatan mikroskopis pada isolat jamur endofit putih 2 memiliki hifa dan septa. Pengamatan makroskopik pada isolat jamur endofit hijau 2 yang tumbuh pada medium PDA memiliki warna permukaan koloni hijau dengan tepi putih, bentuk koloni circular dan elevasi flat dengan permukaan halus. Pengamatan mikroskopis pada isolat jamur endofit hijau 2 memiliki hifa. Dari lima isolat jamur endofit rimpang kunyit hitam hanya satu yang dapat diidentifikasi sebagai Penicillium dan keempat isolat jamur endofit lainnya belum dapat diidentifikasi karena tidak adanya konidia yang tumbuh.

\section{KESIMPULAN}

Hasil isolasi jamur endofit rimpang kunyit hitam (Curcuma caesia Roxb.) diperoleh lima isolat jamur endofit. Isolat jamur endofit hijau 1 (GT1) diduga merupakan genus Penicillium dan empat isolat jamur endofit lainnya belum dapat diidentifikasi.

\section{DAFTAR PUSTAKA}

Devi, H.P., Mazumder, P.B., dan Devi, L.P. 2015. Antioxidant and Antimutagenic Activity of Curcuma caesia Roxb. Rhizome Extracts. Journal Toxiciology Reports 2: 423-428.

Strobel, G., Daisy, B., Castillo, U., dan Harper, J. 2004. Natural Products from Endophytic Microorganism. Journal of Natural Products 67: 257-268.

Sudewo, B. 2012. Basmi Kanker dengan Herbal. Transmedika Pustaka: Jakarta. 
Vairappan, C.S., Elias, U.M., Ramachandram, T., dan Kamada, T . 2012. Secondary metabolites from Rhizome of Curcuma caesia Roxb. Journal Biochemical Systematics and Ecology 48(12): 107-110.

Zhao, J., Mou, Y., Shan, T., Li, Y., dan Zhou, L. 2010. Antimicrobial Metabolites from The Endhopytic Fungus Pichia guilliermondii Isolated from Paris polyphylla var. Yunnanensis. Jurnal Molekul 15(11): 7961-7970 